\title{
Effect of the Imposition of Sanctions, Fiscus Services \& Morality Tax Services to Tax Compliance in 2021 (Empirical Study of Corporate Taxpayers in Bogor Regency of West Java)
}

\author{
Setianing Rahayu1, MF. Arrozi Adikara ${ }^{2}$ \\ 1,2 Universitas Esa Unggul
}

\begin{abstract}
This research aims to review and analyze Sanctions, Fiscus Services \& Morality tax services are tax compliance. The design of this study uses an explanatorical causality design. The population used in this study is a company that becomes a taxpayer in Bogor Regency.The analysis method uses multiple regression analysis and data analysis. The sample selection technique uses probability ampling. The results of this study partially showed that variable tax sanctions had no effect on the compliance of corporate taxpayers. While the fissure service and tax morality affect the compliance of corporate taxpayers, simultaneously showing that tax sanctions, fiscus services, and taxpayer morality together have a significant effect on corporate taxpayer compliance.
\end{abstract}

KEYWORDS: Fiscus Services, Tax Sanctions, Taxpayer Morality and Taxpayer Compliance.

\section{INTRODUCTION}

National development is a government effort that is carried out continuously and continuously in order to improve the quality of community welfare.The main obstacle experienced by the state in implementing national development is about costs.The government needs considerable funds to be able to realize policies and programs related to national development. The funds needed every year also increase along with the increasing needs of the community.

Taxes play a vital role in indonesia's development, as more than $70 \%$ of state revenues come from taxes. Taxes are mandatory contributions to the state owed by private persons or entities that are coercive under the law, with no direct compensation and used for the purposes of the state for the maximum prosperity of the people (Nugraha, 2017; Jumono, 2021).

Taxpayer compliance (tax compliance) can be identified from taxpayer compliance in registering, compliance to re-deposit Notification Letter (SPT), compliance in the calculation and payment of taxes owed, and compliance in payment of arrears.The issue of compliance becomes important because uncertainty will jointly lead to tax avoidance such as tax evasion and tax avoidance, resulting in reduced depositing of funds into state coffers.

Taxpayer compliance is influenced by the morality of the taxpayer, this is because paying taxes is an activity that cannot be separated from the behavior conditions of the taxpayer itself.Moral aspects in the field of taxation concern two things, namely; (1) The moral obligation of the taxpayer in carrying out his tax obligations as a good citizen and (2) concerning the moral awareness of the taxpayer on the allocation of tax revenues by the government.The study found empirical evidence of a significant relationship between taxpayer morality and taxpayer compliance (Thurman et.al., 1984; Troutman, 1993).

Taxpayer morality can be defined as an instrinsic motivation to pay taxes arising from a moral obligation or belief to contribute to the state by paying taxes.Taxpayer morality does not measure individual behavior, but rather individual attitudes and stances.It can be seen as a moral obligation to pay taxes, a belief to contribute to society by paying taxes (Torgler, 2003; Mala, 2021).

Taxpayers who have good capital awareness as citizens in carrying out their tax obligations are different from citizens who do not have moral awareness. Thus it is expected that the musty morality of the taxpayer will increase the tendency of the taxpayer in fulfilling his tax obligations. While tax sanctions are sanctions for taxpayers who do not meet their obligations in accordance with the provisions of Law Number 16 of 2009 concerning applicable tax regulations.Law No.16 of 2009 which regulates the general provisions and procedures of taxation so that tax regulations are adhered to, then there must be tax sanctions for violators. Taxpayers will fulfill their tax obligations if they consider that tax sanctions will do more harm to them (Nugroho, 2006). 


\title{
International Journal of Current Science Research and Review
}

ISSN: 2581-8341

\author{
Volume 05 Issue 03 March 2022 \\ DOI: 10.47191/ijcsrr/V5-i3-02, Impact Factor: 5.825 \\ IJCSRR @ 2022
}

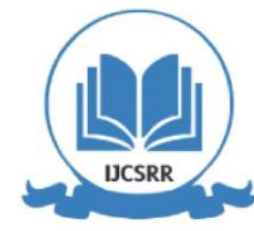

www.ijcsrr.org

Tax sanctions are divided into two types: administrative sanctions and criminal sanctions. Administrative sanctions are legal instruments in the form of administrative sanctions that can be used by tax officials in charge of managing central and local taxes against taxpayers who do not meet the obligations as specified in the General Provisions act and Tax Procedures.For administrative sanctions consist of fines, interest sanctions, and increase sanctions.Administrative sanctions are intended for taxpayers who are considering administrative tax laws.Administrative sanctions are not directed at the physical taxpayer but only in the form of an increase in the amount of taxes owed because there are administrative sanctions that must be paid by the taxpayer.

Sanctions are in place to create a deterrent effect for less compliant taxpayers in terms of their obligations to pay taxes.As per the results of the study (Faiza, 2017) stated that tax sanctions have a positive and significant effect on taxpayer compliance.Taxpayers will meet the payment of taxes if they consider tax sanctions will harm them more.It is also in line with what was stated by (Farandy, 2018) that administrative sanctions have a positive and significant effect on tax compliance.Administrative sanctions contribute to taxpayer compliance, meaning that taxpayers will have compliance with their taxes if there are admisitration sanctions imposed on the taxpayer with applicable regulations.

A fiscus has the responsibility to provide an understanding to the Taxpayer of the importance of paying taxes and reporting tax returns (Kanwil DJP Bengkulu \& Lampung, 2014).Improving the quality and quantity of service is expected to increase satisfaction to taxpayers as customers so as to improve compliance in the field of taxation.Efforts to improve the quality of service can be done by improving the quality and technical ability of employees in the field of taxation, infrastructure improvements such as the expansion of integrated service places (TPT), the use of information systems and technology to be able to provide convenience to taxpayers in fulfilling their tax obligations (Supadmi, 2009).Fiscus services that are cooperative, honest, enforce tax rules, do not complicate, and do not disappoint taxpayers are expected to be able to overcome taxpayer compliance issues. The results of the research that has been done there are still many differences. Yanti, et al (2017) found that tax morality affects taxpayer compliance.In contrast to Ramadan (2017) finding tax morality partially does not affect taxpayer compliance.

\section{THEORY AND DEVELOPMENT OF HYPOTHESES}

\section{Attribution Theory}

The origin of attribution theory is generally explained by Heider (1985), who described his theory as natiive analysis of action.Heider postulates that people give cause to internal and external factors (Schunk, 503:2012). There are two causes of individual behavior, namely behavior caused internally and externally.Internally, the behavior displayed is under the personal control of the individual himself.External behavior is behavior caused from the outside, so the individual is forced to behave because of the situation. This theory assumes that people are inclined to seek information to form attribution (Schunk, 502:2012).

Attribution theory can group two things and can distort the meaning of attribution itself.First, the fundamental attribution error is how the tendency to underestimate the influence of external factors rather than internal factors.Second, there is a service prejudice from one's fault that tends to attribute his success to internal factors alone, whereas failure can be attributed to some external factors.

\section{Tax Sanctions}

Tax Sanctions are a guarantee that the provisions of tax laws and regulations (tax norms) will be followed / obeyed / obeyed. Or it could be in other words tax sanctions are a preventive tool so that taxpayers do not violate tax norms (Mardiasmo, 2016: 62). A taxpayer will fulfill his tax obligations if he considers that the Tax Penalty will harm him more.

\section{Fiscus Service}

According to Kotler the notion of quality is the overall nature and character of a product or service, based on its ability to express satisfaction or needs indirectly. Goetsch \&Davis (2010) defines quality as "dynamic conditions related to products, services, human resources, processes and environments that meet or exceed expectations". According to Kotler (2002:83) the definition of service is any action or activity that one party may offer to another party, which is essentially intangible and does not result in any ownership.The term fisscus according to Ali (1993:31) in (Isyatir, 2015) comes from latin, meaning: basket containing money or pockets of money.

\section{Taxpayer Morality}

Taxpayer morality is a key determinant that can explain why people are honest in tax matters (Nur Cahyonowati, 2011:164).Benno Torgler quoted by Widi Widodo (2010: 9) that tax morals can be defined as the motivation that arises in individuals to pay taxes.This 


\title{
International Journal of Current Science Research and Review
}

ISSN: 2581-8341

\author{
Volume 05 Issue 03 March 2022 \\ DOI: 10.47191/ijcsrr/V5-i3-02, Impact Factor: 5.825
}

IJCSRR @ 2022

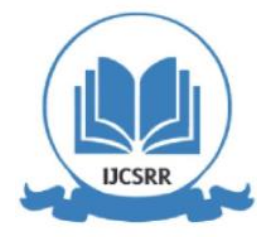

www.ijcsrr.org

motivation can arise from a moral obligation or belief to contribute to the state by paying taxes, or is an individual's willingness to pay taxes.

\section{Taxpayer Compliance}

According to Abdul Rahman's research (2016: 32) taxpayer compliance can be defined as circumstances in which the Taxpayer fulfills all tax obligations and exercises his or her tax rights.So, Taxpayer Compliance is when the Taxpayer can fulfill all his tax obligations by registering, calculating and paying taxes owed, paying arrears and re-depositing the notification letter.

\section{The Effect of Tax Sanctions, Fiscus Services and Taxpayer Morality on the compliance of private taxpayers}

According to Mardiasmo (2012) Tax Sanctions are a guarantee that the provisions of tax laws and regulations (tax norms) will be followed or obeyed, in other words Tax Sanctions are a deterrent so that taxpayers do not violate tax norms. Tax sanctions are a last tool or legal fortress used by the fisss so that tax norms are adhered to.Tax sanctions are imposed on taxpayers who do not comply in fulfilling tax obligations (Arinta Wulan Sari, 2015).

Society is reluctant to pay taxes, it can be due to the intellectual and moral development of society, the elusive tax system, and the control system that is not implemented properly.Moral obligations are individuals who belong to a tax professional, but may not have by another tax professional.(Mardiasmo, 2012).

Wibowo and Yenni (2013) said that the moral of the taxpayer is the compliance and state of the community in carrying out their tax rights and obligations. This factor influences the taxpayer to meet its undeveloped virgin obligations, thus it is necessary to be given tax sanctions to improve taxpayer compliance (Nursiti and Fakhrullah, 2015).

\section{Effect of Tax Sanctions on Taxpayer Compliance}

Tax Sanctions are that the provisions of tax laws and regulations (tax norms) will be followed or obeyed or obeyed or obeyed. Or it could be in other words Tax Sanctions is a deterrent (preventive) so that taxpayers do not violate tax norms (Mardiasmo, 2011: 59).Threats to violations of a tax norm are threatened with administrative sanctions only, some are threatened with criminal sanctions only and some are threatened with administrative sanctions and criminal sanctions.Administrative sanctions and criminal sanctions have differences, namely administrative sanctions are the payment of losses to the state, especially in the form of interest, fines and increases, while criminal sanctions in the form of criminal confinement, or criminal fines and criminals in the form of prison (Nursiti and Fakhrullah, 2015).Taxpayers will comply with tax payments if they consider the penalty will do more harm to him (Ready Wicaksono, 2016).The more remaining tax arrears that must be paid by the taxpayer, the harder it will be for the taxpayer to pay it off.

\section{Effect of Fiscus Services on Taxpayer compliance}

Quality is one of the external factors that cause a person to be obedient.How to find out the attribution provided can be known by looking at the consensus factor in the quality of fissal services. The quality of fiscus service is the attitude of serving the taxman to the taxpayer.In its service, it is expected that the taxpayer will be helped in his tax affairs. The expectation of the taxpayer is certainly smooth in paying his taxes starting from registration, the process up to after payment.The more quality a service is characterized by the satisfaction of taxpayers who are fulfilled.The quality of fiscus services is closely related to the tax system. If the system is simple then the service will be easier to provide.Services that are easy to understand will make the taxpayer satisfied with the services provided.Taxpayers who get service satisfaction will come back again to pay taxes.

\section{The Effect of Taxpayer Morality on Taxpayer compliance}

According to Ajzen in Putri (2012) states that ethics, principles of life, feelings of guilt are moral obligations that every person has in doing something.Moral obligations are not imposed from the outside but commanded from within by the individual conscience and morals. Tax morality is the morality of an individual owned by a person who is likely not owned by others, in this case is an income taxpayer.Such as ethics, the principle of life, feelings of guilt that will be associated with the fulfillment of tax obligations in this case for compliance with taxpayer reporting of income people. With healthy morals and honesty free from negative influences, taxpayers can fulfill obligations in taxation. The rate of tax compliance will become higher when taxpayers have stronger moral obligations (Handayani, 2009). 


\section{International Journal of Current Science Research and Review}

ISSN: 2581-8341

Volume 05 Issue 03 March 2022

DOI: 10.47191/ijcsrr/V5-i3-02, Impact Factor: 5.825

IJCSRR@ 2022

www.ijcsrr.org

Khaerunnisa and Wiratno's research (2015) under the title The Influence of Tax Morality, Tax Culture, and Good Governance on Taxpayer Compliance shows the result that tax morality is an instrinsic motivation to pay taxes arising from moral obligations or beliefs to contribute to the state by paying taxes.

\section{Hypothesis Development}

Based on the literature review and the results of previous research, the hypotheses compiled are as follows:

$\mathrm{H}_{1}$ : Tax sanctions, fiscus services and taxpayer morality affect the compliance of corporate taxpayers.

$\mathrm{H}_{2}$ : Tax sanctions affect the compliance of the Agency's taxpayers.

$\mathrm{H}_{3}$ : Fiscus services affect the compliance of the Corporate taxpayer.

$\mathrm{H}_{4}$ : The morality of the taxpayer affects the compliance of the corporate taxpayer.

\section{RESEARCH METHODS}

\section{Population and Sample}

A population is a collection of individuals who already have established qualities and traits.And based on these qualities and traits, a population will be understood as a group of individuals or objects of observation that will have at least one similarity and characteristics. The population in this study is the corporate taxpayers (WP Badan) in Bogor regency.Based on data from KPP in Bogor regency, until the end of 2021. Not all wp effective bodies are the object in this study because of the enormous amount and the time and cost efficiency that will occur. Then sampling is done.

\section{Operational Definition of Variables}

Compliance of the Taxpayer, Rahman (2016: 32) states that taxpayer compliance is when the taxpayer can fulfill all his tax obligations including registering, calculating and paying taxes owed, paying arrears and re-depositing a notification letter. According to Wardani \& Rumiyatun, (2017) the dimensions of tax compliance are: 1.Fulfill tax obligations in accordance with applicable provisions, 2.Pay his taxes on time, 3.Taxpayers meet the requirements in paying their taxes, 4.Taxpayers can find out the payment is due.

Palupi, 2019) sanctions are negative penalties to people who violate the rules, and fines are penalties by paying money for violating applicable rules and laws, so it can be said that fines are negative penalties to people who violate the rules by paying money.Indicators of Tax Sanctions according to M.Zain, (2013: 83): First: Tax sanctions imposed for violators of tax rules are quite severe or according to the small number of violations.Second: The imposition of severe sanctions is one of the means to educate taxpayers. Third: Tax sanctions must be imposed in accordance with the rules and regulations to violators without tolerance.

Wp's attitude towards fissure services is also an attitude or constellation of cognitive, affective and conative components that will interact in sensing how the service of the real fiscus occurs (Suyatmin, 2004). According to Sari \& Susanti (2014) about the ministry of the fissure can be measured by the following dimensions: 1.The ability to provide satisfactory service; Providing services with the response, ability, decency and trustworthiness of the tax authorities; 3.Have a good communication relationship; Understand the needs of the taxpayer; The availability of physical facilities including adequate means of communication, and employees who are capable of their duties.

Noviyanti (2013) introduces the existence of a moral tax or also called the intrinsic motivation of individuals to act, which is based on values influenced by cultural norms.Several factors that affect tax morale such as: a. Perception of honesty, b.Attitude of helping or serving from apparat, c.Trust in government agencies, d.Appreciation or respect of the tax authorities

\section{RESULTS AND DISCUSSION OF RESEARCH \\ Results}

The results of research on the compliance of corporate taxpayers at the tax service office in Bogor Regency through the influence of tax sanctions, fiscus services and taxpayer morality.The general picture of respondents included age, gender, age, education and occupation. The questionnaire was distributed using google form to 230 respondents, namely companies that became corporate taxpayers in Bogor Regency. Based on the results of google form, which filled out a questionnaire there were only 138 respondents, and at the same time became a sample processed in this study. 


\section{International Journal of Current Science Research and Review}

ISSN: 2581-8341

Volume 05 Issue 03 March 2022

DOI: 10.47191/ijcsrr/V5-i3-02, Impact Factor: 5.825

IJCSRR@ 2022

www.ijcsrr.org

\section{The validity}

Value of each statement item can be seen in the Corrected Item-Total Correlation value of each statement item.Based on the calculation data of the SPSS correlation coefficient (r) it is known that the entire correlation of variable item X is greater than the table $\mathrm{r}$ or 0.166 , then the instrument is declared valid.

\section{Reliability}

From the results of calculations with the SPSS 20 Program obtained reliability test value or Cronbach's Alpha >0.60, thus it can be said that all variable items can be said to be reliable.

\section{Classic Assumption Test}

Normality Test

From the table above it can be concluded that the data used for this study is normal distribution. This can be traced to the value of Asymp.Sig. (2-tailed) above 0.05 which is 0.137 .Thus data processing can be continued to the next step.

\section{Multicollinearity test}

Based on the table it is known that the tolerance value for tax sanction variables is 0.696 , (X1) and fissure services (X2) is 0.516 and taxpayer morality (X3) is 0.644 . While the VIF value for tax sanction variables (X1) is 1,436 , fissure services (X2) is 1,553 and taxpayer morality (X3) is 1,938 . Thus because the value of tolerance $\neq 0$, and the VIF value obtained $<10$, it can be said that there is no significant relationship between independent variable

\section{Autocorrelation Test}

Based on the value of Durbin-watson obtained by 1,508.Durbin-watson value is a limit of $0<\mathrm{dw}<\mathrm{dl}$ or $0<1,508<1,766$ which indicates no positive autocorrelation symptoms. Once it is known that the data used is free from multicollinearity and autocorrelation, regression equations can be established.

\section{Heteroskedasticity Test}

Based on the image it can be known that there is no clear pattern, as well as the points spread above and below the number 0 on the $\mathrm{Y}$ axis.Thus, it can be concluded that there is no heteroskedasticity.

\section{Multiple Linear Regression Test}

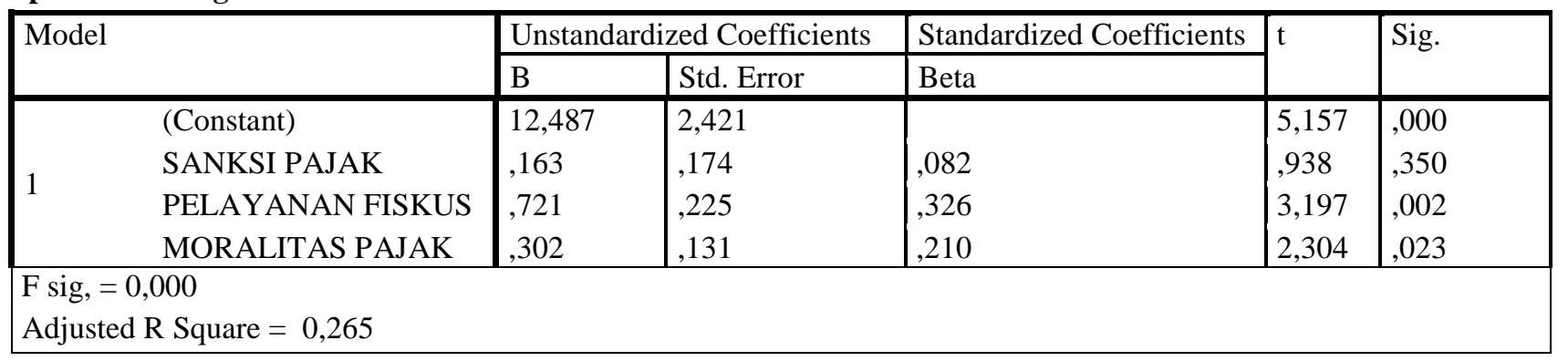

Based on the output above, they:

$$
\mathrm{Y}=\mathbf{1 2 , 4 8 7}+\mathbf{0 . 1 6 3} X_{1}+\mathbf{0 . 7 2 1} X_{2}+\mathbf{0 . 3 0 2} X_{3}+€
$$

Taxpayer morality and tax sanctions affect the compliance of private taxpayers and significantly show that taxpayer morality, and tax sanctions affect the compliance of private taxpayers.

\section{Discussion}

Effect of Tax Sanctions, Fiscus Services and Taxpayer Morality on Corporate Taxpayer Compliance

Tax sanctions, fiscus services and taxpayer morality affect the compliance of corporate taxpayers. This result can be seen from the significance value of $0.000>0.05$, meaning that tax sanctions, fiscus services and taxpayer morality are felt by taxpayers affecting the level of taxpayer compliance in KPP in Bogor Regency.The simultaneous influence of tax sanctions, fiscus services and taxpayer morality on the level of compliance of corporate taxpayers in KPP in Bogor Regency. 


\title{
International Journal of Current Science Research and Review
}

ISSN: 2581-8341

\author{
Volume 05 Issue 03 March 2022 \\ DOI: 10.47191/ijcsrr/V5-i3-02, Impact Factor: 5.825 \\ IJCSRR @ 2022
}

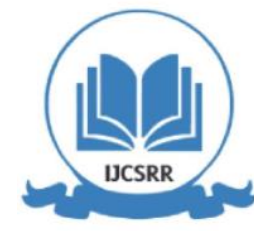

www.ijcsrr.org

This result is in accordance with the attribution theory which shows that the taxpayer who in this case is a body tends to pay attention to external factors that are considered to be factors that can support the smooth running of his own business.Fissure servants, sanctions that are external factors become the basis in every decision-making by the company.That is, when the service is good, then as a taxpayer will also not be lazy in carrying out their obligations such as reporting tax returns.Likewise, tax sanctions, when the company later commits tax-related violations of course the sanctions are waiting for it, and do not rule out the possibility in the future will have difficulties in terms of administrative management related to the government.This makes the company or taxpayer will tend to comply with its tax obligations. The results of this study are also supported by the statement put forward by Jatmiko (2016), taxpayer compliance is defined as entering and reporting on time the necessary information, correctly filling out the amount of taxes owed and paying taxes in time without coercive measures.

\section{Effect of Tax Sanctions on Corporate Taxpayer Compliance}

The results of this study showed that tax sanctions had no effect on taxpayer compliance with KPP in Bogor Regency.This result can be seen from the significance value of $0.350>0.05$, meaning that the hypothesis is rejected, which means that if tax sanctions are applied firmly and clearly it will not increase taxpayer compliance. The taxpayer's perception of the sanctions that are still low is evidenced in the respondents' answers are still low.Indicators of criminal sanctions imposed for tax offenders are very mild.Due to the taxpayer's perception of administrative and criminal sanctions that are still mild, this causes sanctions to have no effect on improving taxpayer compliance but therefore there needs to be follow-up from the government.

Based on the results of this study provides a factual picture that the provision of tax sanctions does not make tax compliance good.This is likely due to the supervision factor of the weak leadership on depositing and reporting so that tax sanctions are not used as something that has an impact on the treasurer himself.Not only that, a small sanction in the form of a $2 \%$ penalty is widely given by the corporate taxpayer, so the application of sanctions is still not effective because there are still taxpayers who are late to pay taxes owed.

\section{Effect of Tax Fiscus Services on Corporate Taxpayer Compliance}

The results of this study show that fiscus services affect taxpayer compliance with KPP in Bogor Regency.This result can be seen from the significance value of $0.002<0.05$, meaning the accepted hypothesis. Taxpayers who get a good quality of service from the fissure will tend to be obedient in paying their tax obligations. Thus, the higher the quality of service provided by the fisss to the taxpayer, the higher the level of taxpayer compliance.

The existence of services supported by facilities such as extensive parking and air-conditioned places, electronic queue numbers, tax forms, the availability of banks in one KPP area makes it easier for taxpayers to pay and report tax returns, at one time, IT support or e-system. With these facilities it can be said that the Bogor regional KPP has provided good service, so that taxpayers feel satisfied and can finally improve the compliance of taxpayers in carrying out their obligations.

This result is in line with research conducted by Kundalini (2016) stating that tax services affect taxpayer compliance. Where the better and quality of fiscus services, the higher the compliance of taxpayers.However, this study is not in line with research conducted by Siahaan and Halimatusyadiah (2018) which revealed that fissure services have no effect on taxpayer compliance.Amrul and Kisnawati (2014) found that fissure services had no effect on taxpayer compliance.

\section{The Effect of Taxpayer Morality on Corporate Taxpayer Compliance}

The results of this study showed that the morality of taxpayers had no effect on taxpayer compliance with KPP in Bogor Regency.This result can be seen from the significance value of $0.023>0.05$, meaning the hypothesis is accepted.Taxpayers who have a moral responsibility in carrying out their tax obligations will tend to be obedient in carrying out their tax obligations. Taxpayers who have good moral awareness as citizens in carrying out their tax obligations are different from citizens who do not have moral awareness. Thus it is expected that the morality aspect of the taxpayer will increase the tendency of the taxpayer in fulfilling his tax obligations.

\section{Research Findings}

Based on the results of the research that has been done above, there are several findings obtained as follows: First, these results are in accordance with the attribution theory that has been described earlier. Especially in the independent variable of fiscus services, the better the facilities provided by tax servants to taxpayers, especially corporations, the more compliance taxpayers to be more 


\title{
International Journal of Current Science Research and Review
}

ISSN: 2581-8341

\author{
Volume 05 Issue 03 March 2022 \\ DOI: 10.47191/ijcsrr/V5-i3-02, Impact Factor: 5.825 \\ IJCSRR@ 2022
}

www.ijcsrr.org

compliant in performing their obligations in paying taxes or reporting their SPT.Second, better service will certainly provide convenience for taxpayers in fulfilling their tax obligations. The results of the study showing the absence of the influence of sanctions on taxpayer compliance gave a new view to researchers that the high sanctions received by taxpayers are not solely due to the noncompliance of taxpayers in reporting their STS.There are indications that the sanctions received by the taxpayers are due to ignorance in terms of pioneering, causing taxpayers to be given fines.Plus there are new rule changes regarding tax payments.

\section{CONCLUSIONS AND SUGGESTIONS}

\section{Conclusions}

1. Simultaneously this study shows that tax sanctions, fissure services and taxpayer morality influence taxpayer compliance.This gives an idea that if tax sanctions, fiscus services and taxpayer morality are carried out firmly it will affect the compliance of taxpayers who are getting better in the Bogor Regency area, especially for corporate taxpayers.

2. Tax sanctions have no effect on taxpayer compliance with KPP in Bogor Regency.These results show that the taxpayer's perception of sanctions that are still low is evidenced in the respondents' answers are still low.Indicators of criminal sanctions imposed for tax offenders are very mild.Due to the taxpayer's perception of administrative and criminal sanctions that are still mild, this causes sanctions to have no effect on improving taxpayer compliance but therefore there needs to be follow-up from the government.

3. Fiscus service affects taxpayer compliance with KPP in Bogor Regency.Taxpayers who get a good quality of service from the fissure will tend to be obedient in paying their tax obligations. Thus, the higher the quality of service provided by the fisss to the taxpayer, the higher the level of taxpayer compliance.

4. The morality of taxpayers affects tax compliance on KPP in Bogor Regency.Taxpayers who have a moral responsibility in carrying out their tax obligations will tend to be obedient in carrying out their tax obligations.

\section{Suggestions}

1. Improve services so that taxpayers want to pay taxes voluntarily because in principle Indonesian taxes are still self assessment.

2. Increase the number of examiners in the Directorate General of Taxes to improve the quality of law enforcement.

3. Conduct socialization and education activities on an ongoing basis to raise awareness of the importance of paying taxes.

4. The application of tax sanctions can be further strengthened and socialized by providing continuous counseling to taxpayers through means that facilitate in providing socialization such as counseling through regional devices or through mass media, because so far there are rarely severe sanctions against taxpayers who commit violations.

\section{BIBLIOGRAPHY}

1. Amrul Rulsi, \& Kisnawati Baiq. (2014). Pengaruh Sistem Pengendalian Intern, Pengetahuan Pajak, Sanksi Pajak, Dan Pelayanan Fiskus Terhadap Kepatuhan Pajak Bendaharawan Pada Pemerintah Kota Mataram.

2. Faiza, N. (2017). Pengaruh Pemahaman Peraturan Perpajakan, Kesadaran Wajib Pajak, Kualitas Pelayanan dan Sanksi Perpajakan Terhadap Kepatuhan Wajib Pajak.

3. Farandy, M. R. (2018). Pengaruh Sanksi Administrasi, Kesadaran Wajib Pajak, Tingkat Pendapatan dan Modernisasi Sistem Administrasi Perpajakan Terhadap Kepatuhan Wajib Pajak Kendaraan Bermotor. (Studi Empiris pada Wajib Pajak Kendaraan Bermotor Kantor SAMSAT Purbalingga).

4. Goetsch, D. L., \& Davis, S. (2010). Quality Management For Organizational Excellence: Introduction to Total Quality. Printice Hall International, Inc.

5. Isyatir Anis Isnaini Nur. (2015). Pengaruh Kualitas Pelayanan Fiskus dan Sanksi Pajak Terhadap Kepatuhan Membayar Pajak Kendaraan Bermotor Di Kabupaten Karanganyar Tahun 2014.

6. Jatmiko, A. N. (2016). Pengaruh Sikap Wajib Pajak Pada Pelaksanaan Sanksi Denda, pelayanan Fiskus dan Kesadaran Wajib Pajak Terhadap Kepatuhan Wajib Pajak Empiri Terhadap Wajib Pajak Orang Pribadi. 


\section{International Journal of Current Science Research and Review}

ISSN: 2581-8341

Volume 05 Issue 03 March 2022

DOI: 10.47191/ijcsrr/V5-i3-02, Impact Factor: 5.825

IJCSRR @ 2022

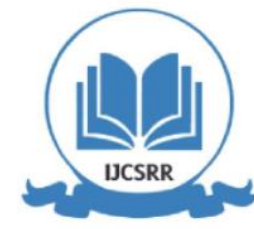

www.ijcsrr.org

7. Jumono, Sapto, Muhammad Dhafi ISKANDAR, Muhammad Fachrudin Arrozi ADHIKARA, Chajar Matari Fath MALA, 2021, Bank Liquidity and Economic Development in Underdeveloped Regions: An Empirical Study in Indonesia, Journal of Asian Finance, Economics and Business Vol 8 No 7 (2021) 0031-0042.

8. Kundalini, \& Pertiwi. (2015). Pengaruh Kesadaran Wajib Pajak Dan Pelayanan Pegawai Pajak Terhadap Kepatuhan Wajib Pajak Pada Kantor Pelayanan Pajak Pratama Kabupaten Temanggung Tahun 2015.

9. M Zain. (2010). Kepatuhan Wajib Pajak Orang Pribadi, Manajemenm Perpajakan. Salemba Empat.

10. Mala, Chajar Matari Fath, Joel Faruk Sofyan, Muhammad Fachrudin Arrozi Adhikara, Sapto Jumono, THE RELATIONSHIP BETWEEN BANKING INTERMEDIATION AND REAL ECONOMIC GROWTH (A CASE STUDY OF INDONESIA FOR THE PERIOD 2007-2019), JOURNAL OF SOUTHWEST JIAOTONG UNIVERSITY, Vol. 56 No. 6 .

11. Mardiasmo. (2016). Perpajakan Edisi Terbaru 2016. Andi.

12. Nugroho, A. (2006). Pengaruh Sikap Wajib Pajak pada Pelaksanaan Sanksi Denda, Pelayanan Fiskus dan Kesadaran Perpajakan terhadap Kepatuhan Wajib Pajak (Studi Empiris terhadap Wajib Pajak Orang Pribadi di Kota Semarang).

13. Nursiti, \& Fakhrullah. (2015). Disparitas Penjatuhan Pidana Kurungan Pengganti Pidana Denda Dalam Putusan Kasus Narkotika. Jurnal Ilmu Hukum.

14. Palupi, \& Nofi Ana Sri. (2019). Pengaruh Kualitas Pelayanan Fiskus, Sanksi Pajak dan Pengetahuan Perpajakan Terhadap Kepatuhan Wajib Pajak dalam Membayar Pajak Kendaraan Bermotor di UPPD Kabupaten Purbalingga dengan Kesadaran Perpajakan Sebagai Variabel Intervening.

15. Putri, A. R. S. (2012). .Faktor-faktor yang mempengaruhi kepatuhan wajib pajak dalam membayar pajak kendaraan motor di Denpasar.

16. Rahman Abdul. (2015). Administras iPerpajakan. Nuansa.

17. Sari, R. A. V. Y., \& Susanti N. (2014). Faktor-Faktor Yang Mempengaruhi Kepatuhan Wajib Pajak Dalam Membayar Pajak Kendaraan Bermotor ( PKB ) Di Unit Pelayanan Pendapatan Provinsi ( UPPP ) Kabupaten Seluma. Jurnal IEkombis Review, 2 (1), 63-78.

18. Schunk, D. H. (2012). Learning Theories: An Educational Perspectives (6th ed.). Pearson Education Inc.

19. Siahaan Stefani, \& Halimatusyadiah. (2018). Pengaruh Kesadaran Perpajakan, Sosialisasi Perpajakan, Pelayanan Fiskus, Dan Sanksi Perpajakan Terhadap Kepatuhan Wajib Pajak Orang Pribadi.

20. Supadmi, N. L. (2009). Meningkatkan Kepatuhan Wajib Pajak Melalui Kualitas Pelayanan. Jurnal Akuntansi \& Bisnis, 4 (2), 1-14.

21. Suyatmin. (2004). Pengaruh Sikap Wajib Pajak Terhadap Kepatuhan Wajib Pajak Dalam Pembayaran Pajak Bumi dan Bangunan: Studi Empiris di Wilayah KP PBB Surakarta.

22. Torgler, B. (n.d.). Tax Morale and Institutions. www.crema-research.ch

23. Troutman., C. S. (1993). Moral Commitment To Tax Compliance as Measured by The Development of Moral Reasoning and Attitutes Towars The Fairness of The Tax Laws.

24. Wardani Dewi Kusuma, \& Rumiyatun. (2017). Pengaruh Pengetahuan Wajib Pajak, Kesadaran Wajib Pajak, Sanski Pajak Kendaraan Bermotor, Dan Sistem Samsat Drive Thru Terhadap Kepatuhan Wajib Pajak Kendaraan Bermotor. Jurnal Akuntansi , 5 (1), 15-24.

25. Wibowo, S., \& Yenni Mangoting. (2013). Analisis Faktor-Faktor Yang Memotivasi Manajemen Perusahaan Melakukan Tax Palanning. Jurnal Tax \& Accounting Review, 1 (1).

26. Widi Widodo. (2010). Moralitas, Budaya, dan Kepatuhan Pajak. Alfabeta.

27. Yanti Sri. (2017). Pengaruh Sikap Wajib Pajak, Moralitas Pajak Dan Keadilan Distributif Terhadap Tingkat Kepatuhan Wajib Pajak Orang Pribadi Dalam Membayar Pajak Pada Kantor Pelayanan Pajak Pratama Gianyar.

Cite this Article: Baburam Mandal, Dr. S. Karmakar, Dipak Bej (2022). Morphological Changes on Gungata River Watershed due to Anthropogenic Interferences, a part of the Upper Rihand Basin, Chhattisgarh. International Journal of Current Science Research and Review, 5(3), 617-624 